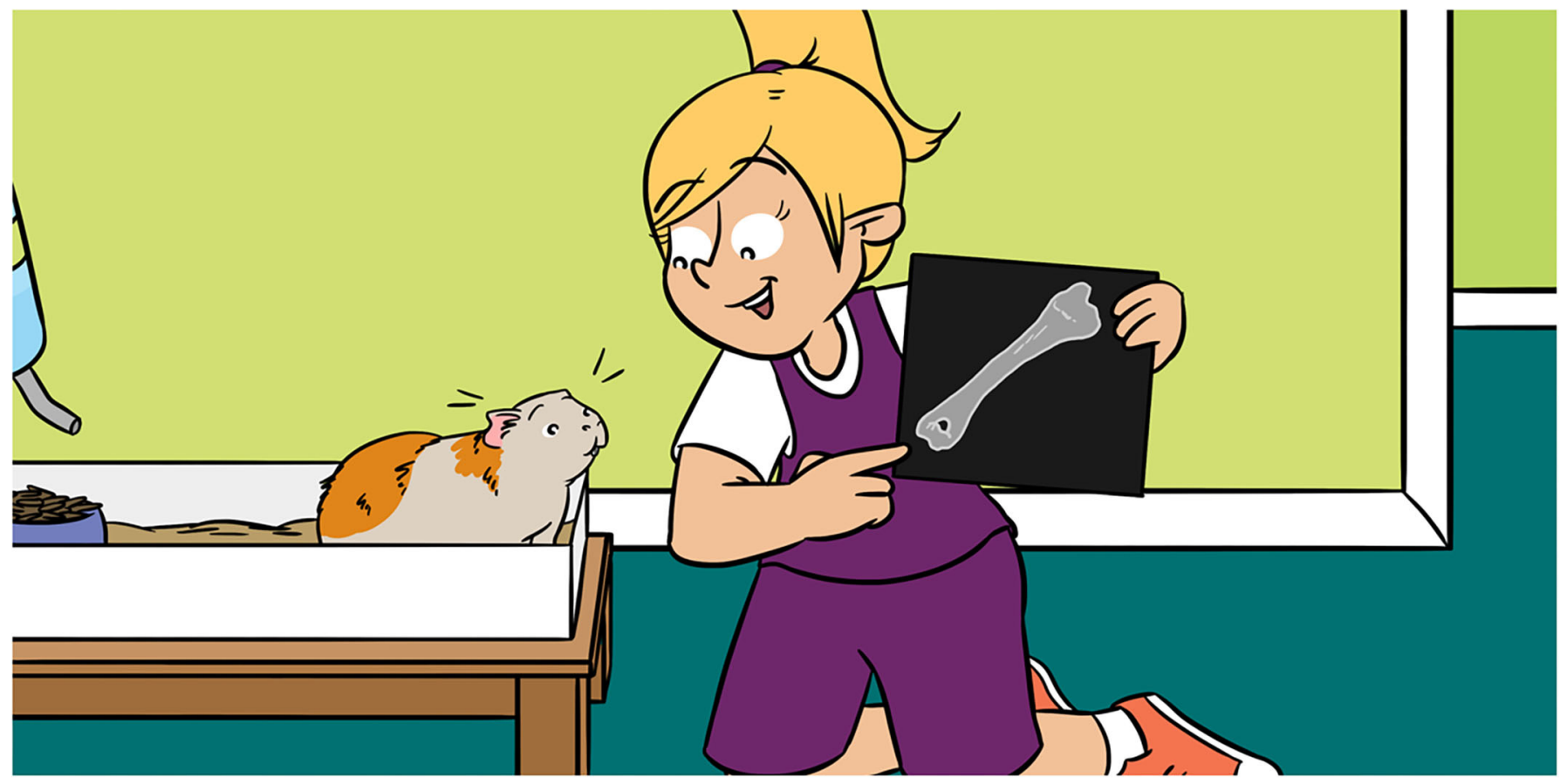

\title{
SKELETON GROWTH IN GUINEA PIGS AND HUMANS
}

\section{Zoe Skinner ${ }^{1}$, Natasha Clark ${ }^{1}$, Sharon Rutland ${ }^{2}$, Andrew Dawkins ${ }^{3}$ and Catrin Sian Rutland ${ }^{1 *}$ \\ ${ }^{1}$ School of Veterinary Medicine and Science, University of Nottingham, Sutton Bonington, Loughborough, United Kingdom ${ }^{2}$ Teacher and Independent Copy-Editor, Derby, United Kingdom \\ ${ }^{3}$ Derby Adult Learning Service, Derby, United Kingdom}

\section{YOUNG REVIEWERS:}

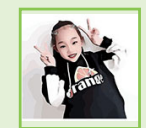

HUIHE

AGE: 8

JINGKAI

AGE: 13

MENG

AGE: 15

OLIVER

AGE: 11
Every animal has a skeleton made up of many different bones. Bones are vital. Without bones we would not be able to move, protect our internal organs, store important minerals, or even make some cell types! When we are young, in addition to growing, our bones must develop into specific shapes. This article describes how and why bones grow and heal in humans and guinea pigs. Using a special imaging technique called micro-computed tomography, we will show you the unique structure of some guinea pig bones and how animals of different ages have important bone variations. We will also discuss how the fascinating discovery of a hole in a bone, called a supratrochlear foramen, was described for the first time in a species. We will also answer questions, such as "how can you keep your bones healthy" and "what happens to astronauts' skeletons in space?" 


\section{PERIOSTEUM}

[pair-ee-os-tee-uhm] A membrane made up of tissue, blood vessels, and nerves that surrounds bone to deliver oxygen and nutrients.

\section{OSSIFICATION}

[os-uh-fi-kay-shunn] The process of forming new bone.

\section{GROWTH PLATE}

Areas near the end of long bones, where new bone growth takes place.

\section{WHAT ARE BONES?}

The number of bones in the human body varies throughout life. Did you know that we have around 270 bones at birth, but this decreases to around 206 when we are adults because some bones fuse together? A guinea pig has 258 bones. Although many mammals, such as humans and guinea pigs often have similar skeletons, the number and shapes of each animal's bones can be different.

There are five basic types of bone. (1) Long bones support the weight of your body and help you to move. They are found in your arms and legs. (2) Short bones allow movement through your joints whilst keeping them stable, for example, in your wrists and ankles. (3) Flat bones protect the organs inside your body, for example, skull bones shield your brain from harm. (4) Irregular bones have different shapes to help them protect organs, such as vertebrae bones in your spinal column (backbone). (5) Sesamoid bones, such as your kneecaps, are small, round bones embedded in tendons (structures that attach muscles to bones), protecting tendons from damage.

Most bones are made from the same basic components (Figure 1). The outer layer of bone is called the periosteum, and it contains nerves and blood vessels. The second layer is solid bone, which is the smooth bone you see when looking at a skeleton. The next layer is called spongy bone, which looks like strands of spaghetti but still feels strong and hard. The final layer is bone marrow, which produces the red blood cells that distribute oxygen and nutrients throughout your body [1].

Although bones may look like dead objects, they are truly alive, made up of living cells. Bones can also adapt. An Olympic athlete's bones will change shape depending on the exercises they do, but so will yours if you play sports. Astronauts lose bone mass when they are in space, at the rate of $1-2 \%$ per month. This could be a big problem for long-term space travel, especially when astronauts arrive back on Earth with weaker bones.

\section{HOW DO BONES GROW?}

When you were still a baby growing inside your mother, your skeleton began life as cartilage, not bone. Cartilage is solid but flexible, which is useful when living inside the small space of the womb. It also enables safer childbirth. As you grow, some parts of your body remain as cartilage while other parts ossify, or become bone, a process called ossification. Areas of the bone called growth plates are made up of cartilage and help new bone to form (Figures 2A,B). Initially, new cartilage forms at the growth plates. This cartilage is then ossified, allowing bones to become longer. 
Figure 1

(A) A micro-CT image of a guinea pig femur bone. (B) Drawings of the bone and a cross-section (through the middle) show the four main layers of bones: the periosteum, containing lots of blood vessels and nerves, solid bone, spongy/trabecular bone, and bone marrow.

\section{OSTEOBLAST}

[os-tee-oh-blast] Cells that help create bones when we are growing, have a fracture/broken bone, and to keep our bones healthy.

\section{OSTEOCLAST}

[os-tee-oh-klast] Cells that break down bone. They help reshape, heal, or grow bones and destroy old or dying cells.

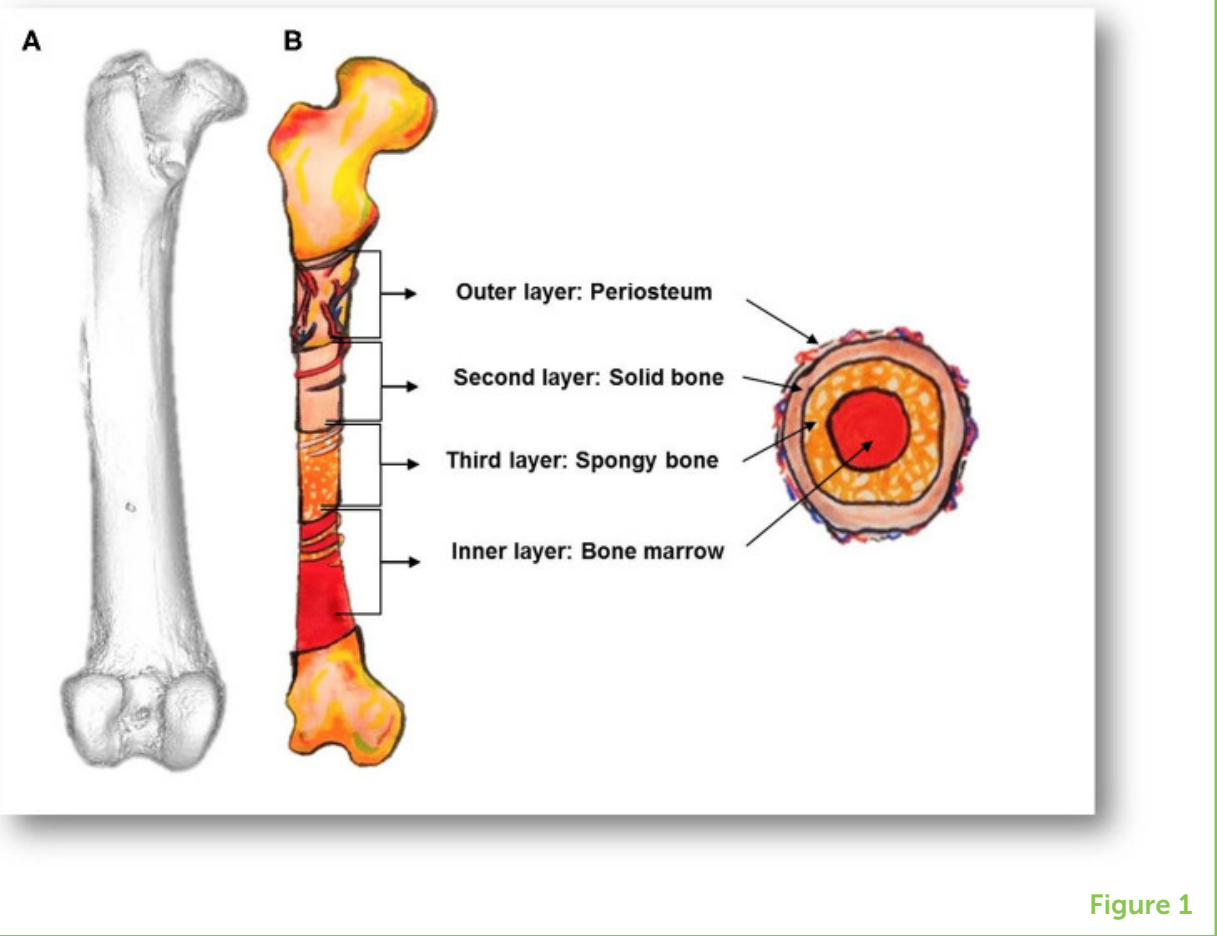

When you reach puberty, the creation of new cartilage at the growth plates stops. Eventually, the growth plate itself becomes ossified. Most long bones stop growing longer by the age of 18 for females and 21 for males. Most bone growth stops completely by the age of 25, except for general repair and maintenance. The length of your bones, and therefore your height, is controlled by many factors including the genes you inherit from your parents, what you eat and drink, how much exercise you do, and even the hormones present in your body.

Throughout life, your bones also grow in width. Special bone-creating cells called osteoblasts, located in the periosteum layer, lay down new bone along the outside of existing solid bone (Figures 1, 2B,C). Special bone-eating cells called osteoclasts remove old bone from the center, meaning the solid bone layer remains the same thickness, but the bones increase in width [2].

While the majority of bone growth happens before the age of 25, your bones still constantly adapt when you are an adult-we call this remodeling. Osteoclasts remove damaged bone, and osteoblasts lay down new bone onto the same surface (Figure 2C). This happens if you have a bone that is healing after it is broken, or just to replace older bone to keep it healthy. Your bones are probably remodeling right now. 
Figure 2

(A) How bone is created; (B) how bone grows; and $(\mathbf{C})$ how bone remodels and repairs. Cells called osteoclasts and osteoblasts help to remove and restore bone. The rightmost image in $A$ is a micro-CT image of a guinea pig humerus.

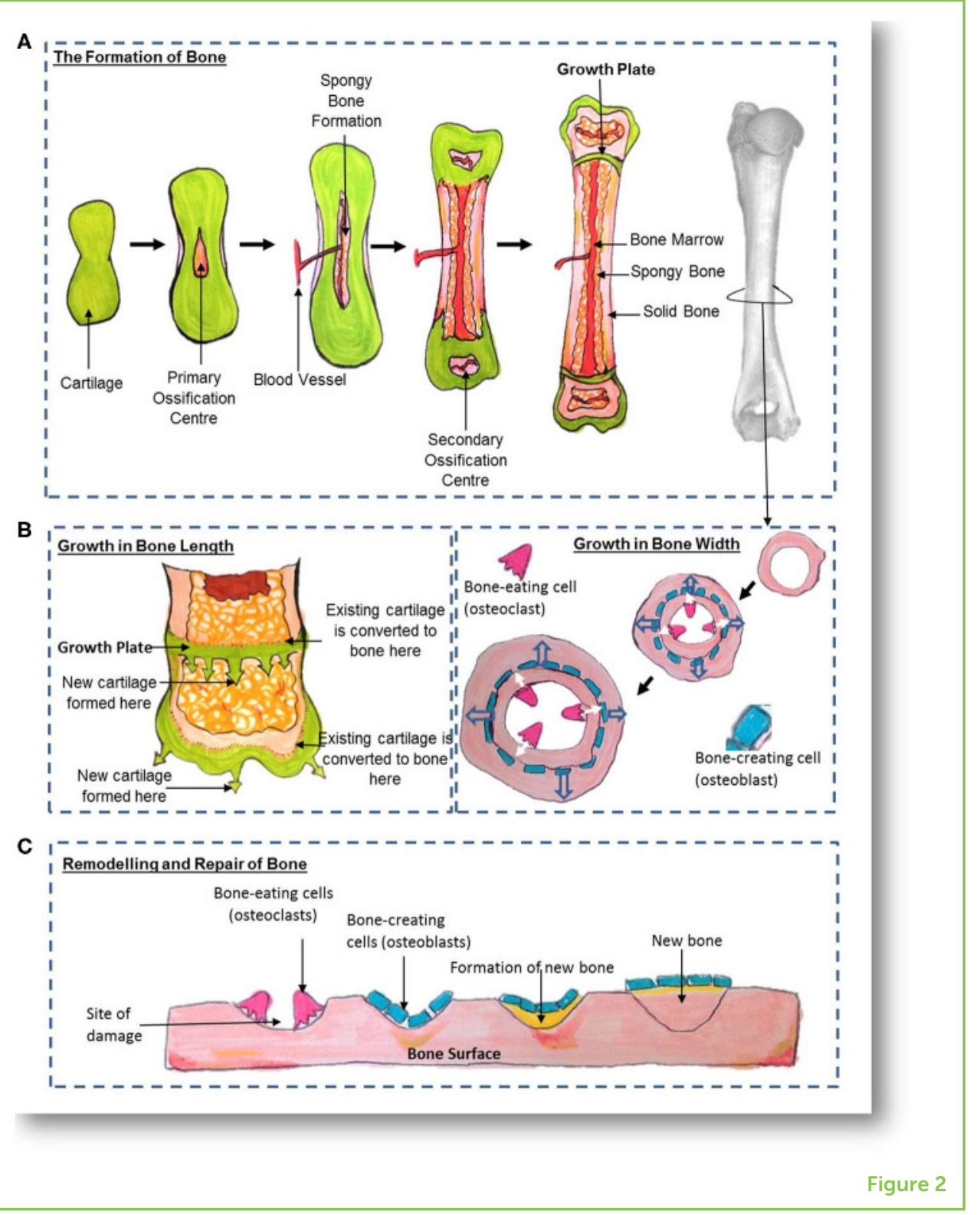

\section{WHY DO BONES BREAK?}

Bones can break for many reasons. Hitting or twisting your bones in an unusual way can cause them to break. Alternatively, your bones can become weak for many reasons, such as aging, eating a poor diet, not being active enough, or because of a disease or illness. These factors can all reduce the rate at which bone cells are replaced and can slow down healing times. At different stages of development, your bone thickness, size, and structure will vary, and this can increase or decrease your chances of breaking a bone.

Your behavior also affects the chances of breaking a bone. Toddlers fall a lot as they learn to walk, which can increase the risk of broken bones. Contact sports, such as rugby or netball, may increase your chances of getting bumped and breaking bones, but exercise does keep your 
Figure 3

Micro-CT images of guinea pig bones. The growth, structure, and supratrochlear foramen (hole in the bone) of the humerus is shown from birth to 4 years. The scapula (shoulder blade) and femur (leg bone) from a

4-year-old show bone thickness using different colors: blue areas are the thickest and red the thinnest. In the lower left is a photograph of Nutmeg the guinea pig, owned by Dr. Siobhan Simpson.
MICRO-COMPUTED TOMOGRAPHY (MICRO-CT)

An imaging technique that uses a computer and narrow $\mathrm{X}$-ray beams to produce a 3D image of an object, such as a bone [4].

\section{SUPRATROCHLEAR FORAMEN}

[soo-pruh-trok-lee-ah fawr-ah-muhn] The scientific name for a hole found just above a part of the humerus bone called the trochlea. The supratrochlear foramen exists in some people and animals but not in others.

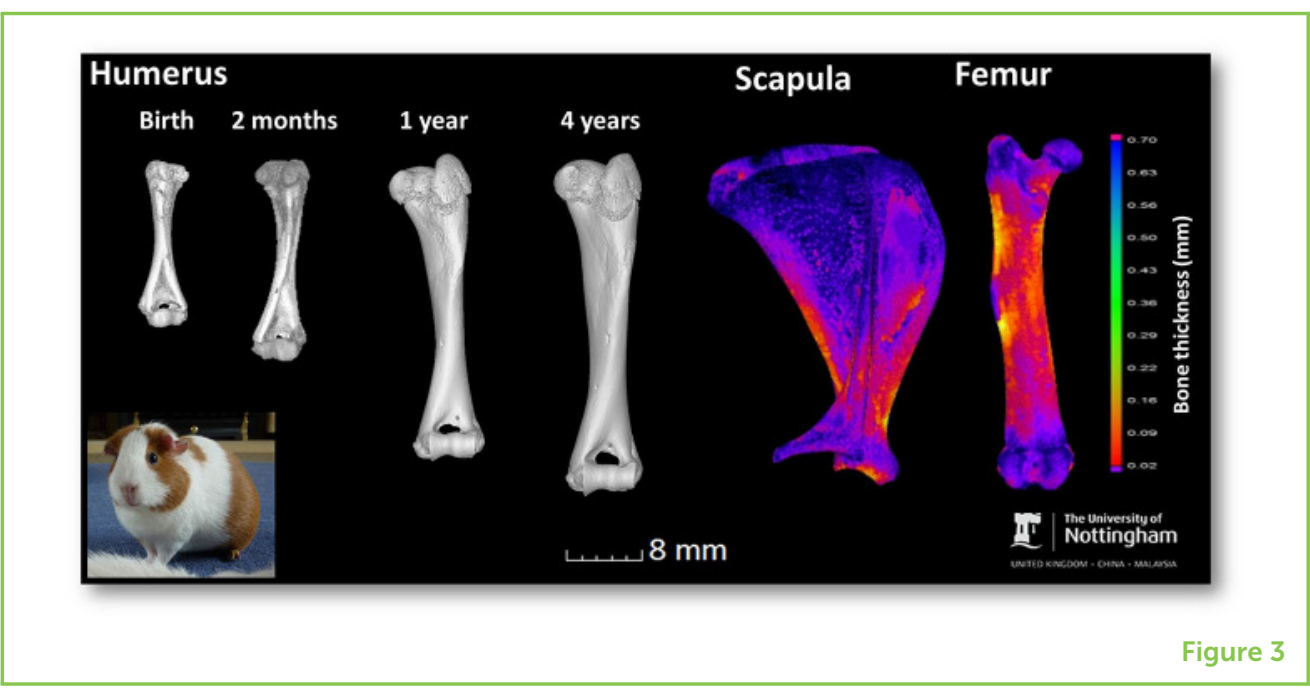

body healthy, too. Bones usually heal better in younger people and animals, which is good news.

\section{RESEARCHING GUINEA PIG BONES}

Millions of guinea pigs across the world are kept as pets. They are also seen as a delicacy in some parts of the world, and are an important source of food. Because they are such important animals, and because veterinary surgeons see lots of pet guinea pigs with broken legs, it is essential to understand as much as we can about their bones.

Researchers at the University of Nottingham conducted a study investigating the thickness, structure, and size of guinea pigs bones at different ages [3]. The research focused on three bones that commonly break and need medical care: the femur, located in the leg, the humerus, in the arm, and the scapula, or shoulder blade.

Micro-computed tomography (micro-CT) is a modern scientific imaging technique that allows us to look at bones and other objects at very high magnifications. The machine uses lots of $x$-ray beams to produce a 3D image. Using micro-CT and other techniques, the researchers showed the thickness of each of the three guinea pig bones and how the bones varied in younger and older animals, just like human bones (Figure 3). In a surprising finding, despite guinea pigs reaching their full adult weight at 8-12 months old, the research showed that bone growth and thickness continued to increase over the age of 1 year! This may explain why guinea pig bones still break relatively easily, even once they reach an adult weight: their bones are still developing.

Another big discovery was that $100 \%$ of the guinea pig humerus bones had a large hole in them, called a supratrochlear foramen (Figure 3). This feature had never been seen in guinea pigs and is 
unusual in many other species. The supratrochlear foramen may help the elbow joint extend and move, but also increase the chances of bone fractures. It is common in rodents that walk on land and less common in tree-living animals, such as monkeys. In humans, the humerus can have a supratrochlear foramen, but not always. The supratrochlear foramen is more common in females and in the left humerus. People from different parts of the world vary in their likelihood of having a supratrochlear foramen. For example, around $1 \%$ of people from Greece have one, $6.9 \%$ of people from the United States, and $18.8 \%$ of people from Japan, but the highest number reported was in Native American Indians from Arkansas, at $52 \%$. Indeed, American Indians in general have a high chance of having this exciting structure [5]. I wonder if one or both of your humerus bones have the hole? It is also interesting that, in children, $58 \%$ of all elbow fractures are in this region of the humerus-could this be linked to the supratrochlear foramen?

\section{HOW CAN HUMANS AND GUINEA PIGS KEEP THEIR BONES STRONG AND HEALTHY?}

You must use your bones so that they grow, develop, and maintain strength. Did you know that muscles and bones interact with each other? Muscles play an essential part in keeping bones strong, as they stop you from putting too much stress/strain on your bones and joints; stress can damage bones. Exercising regularly allows you to build strong and healthy muscles and bones. Therefore, enabling your guinea pig space to run around and keeping yourself active are important.

Your diet is also vital when it comes to bone health and strength. You need the right ingredients and nutrients from the food and drinks you consume to keep cells alive and to heal bones. Therefore, it is important to eat a healthy, balanced diet, including vitamins and minerals (often found in fruit, vegetables, and dairy products). Guinea pigs also need good nutrients [6].

\section{CONCLUSION}

Bones are a fascinating area of anatomy to study. Bones have to enlarge and develop as we grow, they also have to adapt to our changing bodies and the activities we do, they even have to mend if we fracture or break a bone. Imaging guinea pig bones has taught us that their bones continue growing even when the animal looks fully grown from the outside. It also shows that bone thickness varies in different bones and changes as they grow. We now know that guinea pigs have a supratrochlear foramen in their humerus, which is rarely seen in other animals. We hope you agree that bone growth is an interesting research topic and especially important for maintaining 
good health and helping broken bones to heal, in humans, guinea pigs, and all animals.

\section{ACKNOWLEDGMENTS}

Importantly we would like to thank the Anatomical Society for funding via a Public Engagement and Outreach grant to Catrin titled Anatomy for ALL - Making Anatomy Accessible. Part of this work was made possible due to INSPIRE student scholarships funded by The Wellcome Trust, The Academy of Medical Sciences awarded to Drs. Rutland, James, Mongan, Daly, Braithwaite, Voigt, and Cobb. We thank the British Science Association and University of Nottingham for awarding Catrin with a BSA Media Fellowship. Our appreciation also goes to the other authors of the original scientific paper, the BBSRC and University of Nottingham for funding that work and the guinea pig owners.

\section{ORIGINAL SOURCE ARTICLE}

Witkowska, A., Alibhai, A., Hughes, C., Price, J., Klisch, K., Sturrock, C. J., et al. 2014. Computed tomography analysis of guinea pig bone: architecture, bone thickness and dimensions throughout development. PeerJ 2:E615. doi: 10.7717/peerj.615

\section{REFERENCES}

1. Machado, M., Mitchell, C., Franklin, J., Thorpe, A., and Rutland, C. 2020. Blood vessels under the microscope. Front. Young Minds 8:151. doi: 10.3389/ frym.2019.00151

2. Mackie, E. J., Ahmed, Y. A., Tatarczuch, L., Chen, K. S., and Mirams, M. 2008. Endochondral ossification: how cartilage is converted into bone in the developing skeleton. Int. J. Biochem. Cell B 40:46-62. doi: 10.1016/j.biocel. 2007.06.009

3. Witkowska, A., Alibhai, A., Hughes, C., Price, J., Klisch, K., Sturrock, C. J., et al. 2014. Computed tomography analysis of guinea pig bone: architecture, bone thickness and dimensions throughout development. PeerJ 2:E615. doi: $10.7717 /$ peerj.615

4. Keane, M., Paul, E., Sturrock, C. J., Rauch, C., and Rutland, C. S. 2017. "Computed tomography in veterinary medicine: currently published and tomorrow's vision," in Computed Tomography-Advanced Applications, ed A. M. Halefoglu (London, UK:InTechOpen). p. 271-89. doi: 10.5772/intechopen.68556

5. Mathew, A. J., Gopidas, G. S., and Sukumaran, T. T. 2016. A study of the supratrochlear foramen of the humerus: anatomical and clinical perspective. J. Clin. Diagn. Res. 10:AC05-8. doi: 10.7860/JCDR/2016/17893.7237

6. Witkowska, A., Price, J., Hughes, C., Smith, D., White, K., Alibhai, A., et al. 2017. The effects of diet on anatomy, physiology and health in the guinea pig. J. Anim. 
Health Behav. Sci. 1:1-6. Available online at: https://www.hilarispublisher.com/ abstract/the-effects-of-diet-on-anatomy-physiology-and-health-in-the-guinea - pig-32044.html

SUBMITTED: 12 May 2020; ACCEPTED: 12 February 2021;

PUBLISHED ONLINE: 05 March 2021.

EDITED BY: Valerie Gerriets, California Northstate University, United States

CITATION: Skinner Z, Clark N, Rutland S, Dawkins A and Rutland CS (2021) Skeleton Growth in Guinea Pigs and Humans. Front. Young Minds 9:561416. doi: $10.3389 /$ frym.2021.561416

CONFLICT OF INTEREST: The authors declare that the research was conducted in the absence of any commercial or financial relationships that could be construed as a potential conflict of interest.

COPYRIGHT @) 2021 Skinner, Clark, Rutland, Dawkins and Rutland. This is an open-access article distributed under the terms of the Creative Commons Attribution License (CC BY). The use, distribution or reproduction in other forums is permitted, provided the original author(s) and the copyright owner(s) are credited and that the original publication in this journal is cited, in accordance with accepted academic practice. No use, distribution or reproduction is permitted which does not comply with these terms.

\section{YOUNG REVIEWERS}
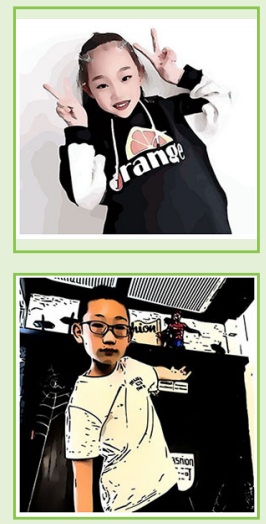

\section{HUIHE, AGE: 8}

Hello! My name is Huihe and I am currently 8 years old. I spend my free time painting and singing. I hope to become a broadcast presenter in the future and also to disseminate the latest research results.

\section{JINGKAI, AGE: 13}

Hey! My name is Jingkai, I am 13 years old and I enjoy playing sports (basketball and bicycle). I like Science and would like to be an inventor in the future.

\section{MENG, AGE: 15}

My name is Meng and I am 15 years old. In my spare time, I like to read and sing. I hope I can become a policewoman in the future.

\section{OLIVER, AGE: 11}

I live in the UK and love playing hockey and cricket, building lego, playing the violin, Xbox, and with my dog. I love films, especially Marvel and Star Wars movies. I also like reading and my favorite author is Patrick Ness. At school, my favorite subjects are science, computing, maths, and English. I hate mushrooms, stuffing 


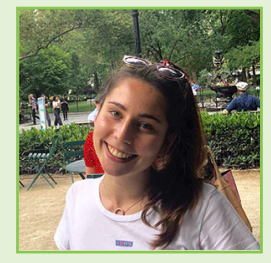

and the Descendants films! When I am older, I want to be a software engineer or a professional hockey player.

\section{AUTHORS}

\section{ZOE SKINNER}

I am a final-year veterinary student at the University of Nottingham. The topics I enjoy studying most are hormones, bones and muscles, and ophthalmology. My favorite animals are cats, and I have two called Jango and Bobba. I love to draw and illustrate for fun, but I also find it a brilliant way to further my understanding of difficult topics! In my spare time, I like to visit galleries and museums, cook, and travel to new places. My favorite way to keep my bones healthy is by playing sports with my friends. My favorite sports to play are badminton and rounders.
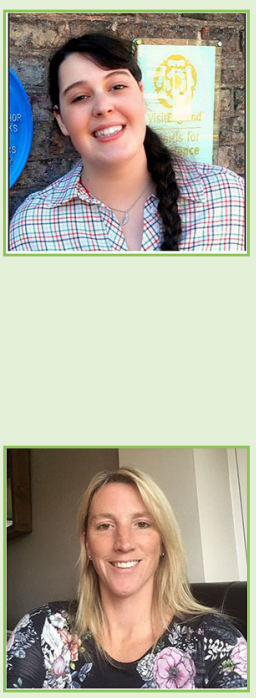

\section{NATASHA CLARK}

I have just graduated as a veterinary surgeon from the University of Nottingham, and have a keen interest in cardiology, dentistry, and zoo medicine. I work in a variety of veterinary practices and zoos. I love art as a hobby and find it very relaxing; art enables me to learn more about anatomy. My dog Poppy and I enjoy taking long walks in the fresh air around National Trust country parks to keep our bones and muscles healthy. In my spare time, I enjoy playing classical guitar, swimming, camping, and attending the theater with friends.

\section{SHARON RUTLAND}

I am a teacher and have taught young people in schools for over 20 years. I am also a professional proofreader and copy-editor and more recently I have written my first children's novel. I have two children, Joshua and Erin, who love learning about animals and science. In my spare time, I enjoy playing tennis to keep my muscles and bones healthy and my passion for the theater and acting keeps my heart racing, especially on opening night.

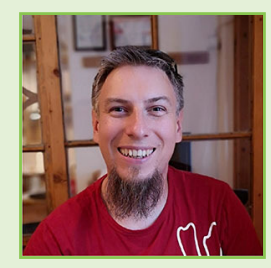

\section{ANDREW DAWKINS}

I am a curriculum manager for mathematics and English and a teacher for mathematics and information technology at Derby Adult Learning Service for the last 10 years. I enjoy windsurfing to keep my bones and muscles active and strong. I have a cat called Twinks and we had a pet guinea pig called Ginger when I was younger.

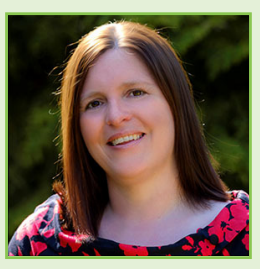

\section{CATRIN SIAN RUTLAND}

I am Associate Professor of Anatomy and Developmental Genetics at The University of Nottingham and 2019 British Science Association Media Fellow. I lead a group of research scientists investigating hearts, bones, and general anatomy, looking for techniques to detect, prevent, and cure illnesses and disorders. When I am not working, I love to travel around the world, visit museums, and write science fiction. I go to the gym with friends and I go running to keep healthy. *catrin.rutlandanottingham.ac.uk 